\title{
The Relationship Between Emotional Intelligence and Students' Attitude Towards Computers: A Study on Polytechnic Engineering Students
}

\author{
Jeya Amantha Kumar \\ Centre of Instructional Technology and Multimedia, Universiti Sains Malaysia, Pulau Pinang, Malaysia \\ Email: jeya.amantha@gmail.com \\ Balakrishnan Muniandy \\ Centre of Instructional Technology and Multimedia, Universiti Sains Malaysia, Pulau Pinang, Malaysia \\ Email: mbala@usm.my \\ Wan Ahmad Jaafar Wan Yahaya \\ Centre of Instructional Technology and Multimedia, Universiti Sains Malaysia, Pulau Pinang, Malaysia \\ Email:wajwy@usm.my
}

\begin{abstract}
Computers are perceived as an important tool in the world of education. Computer technology today when used in teaching and learning could open the world to students. However when learning is concern, emotions relevant to learning should not be forgotten. Thus emotional intelligence should be considered when computers and learning is concern. There is very little research on the effect of emotional intelligence on learning and on technology. As learning with technology relates to computers, thus this study focuses on the relationship between emotional intelligence and attitudes towards computer. Based on this study it was found that emotional intelligence of the polytechnic engineering students was average and their attitudes towards computers were positive. The relationship between emotional intelligence and attitude towards computer is positive but very weak. Significant difference were found when gender was compared however CGPA (Cumulative Grade Point Average) and ownership of computers did not affect this relationship.
\end{abstract}

Index Terms - Attitude towards Computers, Emotional Intelligence, Engineering Education, Emotions

\section{INTRODUCTION}

Computers have affected our lives in many ways. In the field of education, computers are perceived as an important tool to transform how we teach, learn, evaluate learning goals and communicate information. However rapid advancement in computer technology has post a challenge in education as student are required to have the right kind of attitude to keep up with these changes [1]. Challenges in the form of interaction were only studied on how it affected human thinking, but researchers have shown that emotion should also be considered when dealing with computers
[2],[3],[4]. Thus emotions are important in establishing a positive learning environment especially in Human Computer Interaction (HCI) [3].

Emotions are also associated with learning especially in skills that require "high motivation, self-control, and effective self-regulation, along with social skills such as forming constructive learning partnerships and avoidance of damaging antisocial behaviours" [5]. This description of emotional skills does not drop far from the characteristic of a person with high emotional intelligence. Emotional intelligence in the education sector highly impacts the learning process and cognitive intelligence of the learner [6]. Thus learner's emotion not only affects the learning process but also has a significant impact on computer usage as learning can occur from, around or through technology [7]. There is very little research on the effect of emotional intelligence on learning with technology [8]. Thus with the ever changing technology in computing, we can pose a question if there is a relationship between students attitude towards computers and emotional intelligence.

This paper will cover a brief discussion on emotional intelligence in education followed by the seven domains such as emotional control, maturity, etc. Attitude towards computers in education will also be covered in the next section.

\section{A. Emotional Intelligence}

Emotional intelligence (EI) is defined as "the ability to monitor one's own and others' feelings and emotions, to discriminate among them and to use this information to guide one's thinking and actions" [9]. Emotional intelligently people are people that are aware of their emotions and others and are capable of managing these emotions [10]. Goleman defined it as an ability to manage emotion (self and others) so that it is beneficial 
to them and their environment [11]. He describes emotional intelligence as the main contributor to a person's success.

As EI promotes understanding, better relationship, stability and harmony in human relationship [12], it also helps to create balance in a person's education [13]. Balanced student with good emotional knowledge contributes in motivation to engage in learning itself [14]. EI skills in education also motivate students to achieve higher learning goals and broaden their personal development [5]. Students whom possess immature levels of emotional intelligence may be inclined to perceive learning with technology (e.g. online learning) negatively, as it requires self-discipline, independent effort, maturity, time management skills, and positive attitudes [14]. Students with higher EI were found to be naturally achievement - oriented, innovative and highly motivated [15].

There are three theoretical approaches in emotional intelligence; specific ability approach, integrative approach and mixed-model approach [16]. The specific ability approach is a specific skill area that is basic to emotional intelligence that concerns mental capabilities; the integrative approach as a combination of these specific skills to gain emotional intelligence; and the mixed-model approach is an approach that combines diverse skills and intelligence based upon psychological traits, abilities and styles [10].

The model of emotional intelligence used in this study is a mixed-model approach designed specifically for Malaysian respondents. The model has seven dimensions and is described in Table 1 based on how a person with high levels of EI domains are characterise.

\section{B. Computer Attitude}

Attitude is "a relatively enduring organization of beliefs, feelings, and behavioural tendencies towards socially significant objects, groups, events or symbols"[17]. Attitude predicts people's behaviour [18]. Attitude could be divided into three main components; affective, behaviour and cognitive [19]. These components referred as the $\mathrm{ABC}$ model of attitudes are described in Table 2 as per the description provided by McLeod [20]
TABLE 1. DESCRIPTION OF THE SEVEN EI DIMENSIONS

\begin{tabular}{|c|c|}
\hline EI Domains & Description \\
\hline $\begin{array}{c}\text { Emotional } \\
\text { Control }\end{array}$ & $\begin{array}{l}\text { - Ability to control oneself from disturbing } \\
\text { emotions and impulsive feelings. } \\
\text { - Able to handle pressure. } \\
\text { - Able to bounce back from setbacks and } \\
\text { change misfortune into fortune. }\end{array}$ \\
\hline $\begin{array}{l}\text { Emotional } \\
\text { Maturity }\end{array}$ & $\begin{array}{l}\text { - Outcome and achievement oriented } \\
\text { - Operate from hope of success rather than fear } \\
\text { of failure. } \\
\text { - Setbacks are seen as controllable } \\
\text { circumstances rather than a personal flaw. }\end{array}$ \\
\hline $\begin{array}{l}\text { Emotional } \\
\text { Conscientiousnes } \\
\text { s }\end{array}$ & $\begin{array}{l}\text { - Able to take responsibility and maintain } \\
\text { integrity } \\
\text { - Accountable, organized and careful in their } \\
\text { work. }\end{array}$ \\
\hline $\begin{array}{l}\text { Emotional } \\
\text { Awareness }\end{array}$ & $\begin{array}{l}\text { - Able to recognise and understand their } \\
\text { emotion and other internal states, } \\
\text { preferences, resources and intuitions as well } \\
\text { as their effects. } \\
\text { - Aware of values and goals. }\end{array}$ \\
\hline $\begin{array}{c}\text { Emotional } \\
\text { Commitment }\end{array}$ & $\begin{array}{l}\text { - Able to of align and work with others in a } \\
\text { group or organization towards common } \\
\text { goals. } \\
\text { - Able to make sacrifices to meet a larger } \\
\text { organizational goal. } \\
\text { - Able to seek out opportunities to fulfil their } \\
\text { group's mission }\end{array}$ \\
\hline $\begin{array}{l}\text { Emotional } \\
\text { Fortitude }\end{array}$ & $\begin{array}{l}\text { - Able to negotiate and resolve disagreements. } \\
\text { - Are diplomatic. } \\
\text { - Able to admit their own mistakes and } \\
\text { confront unethical actions in others. }\end{array}$ \\
\hline $\begin{array}{l}\text { Emotional } \\
\text { Expression }\end{array}$ & $\begin{array}{l}\text { - Able to convey and adjust their emotions, } \\
\text { thoughts and behaviours to changing } \\
\text { situations and conditions. } \\
\text { - Able to react towards self and others' } \\
\text { feelings effectively. } \\
\text { - Able to display their emotions effectively } \\
\text { using non verbal communications such as } \\
\text { appropriate voice tone, body language and } \\
\text { facial expression. }\end{array}$ \\
\hline
\end{tabular}

TABLE 2. ABC MODEL OF ATTITUDES

\begin{tabular}{|l|l|}
\hline Component & Description \\
\hline Affective & $\begin{array}{l}\text { Affective is the feeling or emotions } \\
\text { that people have towards an object. } \\
\text { For example: "I am scared of spiders". }\end{array}$ \\
\hline $\begin{array}{l}\text { Behaviour } \\
\text { Conative) }\end{array}$ & $\begin{array}{l}\text { Behaviour is the attitude that } \\
\text { influences how a person acts or } \\
\text { behaves. For example: "I will avoid } \\
\text { spiders and scream if I see one". }\end{array}$ \\
\hline Cognitive & $\begin{array}{l}\text { Cognitive is the person's belief or } \\
\text { knowledge about the object. For } \\
\text { example: "I believe spiders are } \\
\text { dangerous". }\end{array}$ \\
\hline
\end{tabular}

Computer attitude relates to behaviour of the user while interacting with the computer hardware, software, users and activities related to the usage of the computer [21]. Computers usage in Malaysia is still very limited [22]. Users whom believe that computers are useful to them will have a positive attitude towards computer [23]. However this perception will increase positively if users are not required to put in much effort when using it [23].

As computers are vital in education [24], integrating computers in higher education would require users to 
have positive attitude, high self-efficacy and low anxiety level when dealing with computers [25]. A study done in Universiti Malaysia Sarawak reported that generally students have a positive attitude towards computers [26]. Undergraduates who are mostly exposed to computers such as engineering and information technology students had more positive attitude compared to other faculties. It was also reported that attitude is critical especially in curriculums that are computer related [27].

Attitude could also be affected by other factors such as motivation, time managements, test strategy and information processing. These factors have significant but small effect towards attitudes towards computers [23]. Computer experience and exposure has a significant impact on forming user's computer attitude. However, the impact can either be positive or negative as the type of experience is subjective to an individual's experience [28]. Personal traits such as gender and age could also affect these attitudes [5],[27],[23]. The effect of gender is somewhat inconclusive. Female users are inclined to have negative attitude towards computers [29] whre else some researchers disagreed as according to them gender would not be a determining factor as computers are ubiquitous tools [19] [25]. Computer ownership could also have a significant impact as it contributes to the experience of computer usage [19] [24]. As people's lives starts to revolve around computers, the skills and knowledge people posses will positively correlate with a person is success [30].

\section{OBJECTIVE}

The purpose of this study is to investigate the relationship between emotional intelligence and attitude towards computers. The objectives of the study are as follow:

i. To investigate the level of emotional intelligence of final year diploma of electronic engineering students based on their gender, computer ownership and CGPA.

ii. To investigate attitude towards computers for the final year diploma of electronic engineering students based on their gender, computer ownership and CGPA.

iii. To investigate if there is a relationship between emotional intelligence and attitude towards computers for the final year diploma of electronic engineering students.

\section{RESEARCH QUESTIONS}

This study plans to answer the following research questions:

i. What is the level of emotional intelligence of final year diploma of electronic engineering students? ii. What is the attitude towards computers for the final year diploma of electronic engineering students?

iii. Is there a significant difference between gender, computer ownership and levels of CGPA among emotional intelligence, attitude towards computers and their domains?

iv. What is the relationship between emotional intelligence and attitude towards computers for the final year diploma of electronic engineering (computers) students?

\section{METHODOLOGY}

The questionnaires were distributed to all final year diploma of electronic engineering (computers) students in a polytechnics in the northern region of Malaysia.

\section{A. Research Instrument}

Two areas were tested in this study; emotional intelligence and attitude towards computers. Both these instruments are dual language and designed for the Malaysian population. The Universiti Sains Malaysia Emotional Quotient Inventory (USMEQ-i) and attitude towards computers questionnaire has high reliability rates which is between 0.94 to 0.97 [31] and 0.86 [19] respectively. These questionnaires were obtained, used and modified with the permission from the authors. The instruments are described below:

\section{The Universiti Sains Malaysia Emotional Quotient Inventory (USMEQ-i)}

The USMEQ- $i$ was developed based on the mixed model approach of emotional intelligence. It has seven scales; emotional control, emotional maturity, emotional conscientiousness, emotional awareness, emotional commitment, emotional fortitude and emotional expression [10]. It has seven items (faking index) to measure the tendency of the respondents to over-rate themselves. The questionnaire consists of 46items and seven of these items represent the faking index domain, leaving the balance 39 items to represent the emotional intelligence dimension. The items are scored based on a 5-point Likert scale; "not like me", " a bit like me" , "quite like me" , "a lot like me", "totally like me".

Computer Attitude Scale (Ibrahim, Wong, \& Ayub, 2011)

This instrument comprehends 29 items and the overall scoring will determine either a positive or negative attitude. The items are scored based on a 5point Likert scale ; "Totally disagree", "Disagree", "Neutral", "Agree", "Totally agree". This instrument will measure attitude based on 3 dimensions; affective, cognitive and behavioural. It has a total of 29 item, in which eight items will measure the affective domain, 13 items to measure the cognitive domain and eight items to measure the behaviour domain. 


\section{FINDINGS}

Out of the 65 questionnaires distributed, a total of 59 questionnaires were returned. Therefore the respond rate was $91 \%$. However 17 questionnaires had to be rejected due to high score in the faking index domain. Thus the usable data are only from the 42 questionnaires.

\section{A. Demographic profile}

Table 3 shows the demographic profile of the respondents. Based on the data, $57.1 \%$ of the respondents were male and $42.9 \%$ were female. $92.9 \%$ of the respondents own computers for personal usage and $61.9 \%$ of the respondents had a CGPA above 2.99 which is also categorised as High.

TABLE 3: DEMOGRAPHIC PROFILE OF RESPONDENTS

\begin{tabular}{|l|c|c|}
\hline Variables & $\mathrm{n}$ & $\%$ \\
\hline Gender & & \\
\hline Male & 24 & 57.1 \\
\hline Female & 18 & 42.9 \\
\hline Computer Ownership & & \\
\hline Yes & 39 & 92.9 \\
\hline No & 3 & 7.1 \\
\hline CGPA & & \\
\hline High $(2.99>)$ & 26 & 61.9 \\
\hline Low $(<=2.99)$ & 16 & 38.1 \\
\hline
\end{tabular}

\section{B. Reliability of the study}

The overall emotional intelligence scale of 39 items had an acceptable internal consistency of Alpha Cronbach coefficient of 0.85 . Where else the computer attitude scale had an acceptable internal consistency of Alpha Cronbach coefficient of 0.92). The reliability of each of the domains in both of the instrument is compared with the original reliability provided by the author in Table 4. Based on the analysis it is found that all the domains had internal consistency below the acceptable level (0.7). It is common in cases where the items are fewer than 10 item, thus suggesting to report the mean inter item correlation for the items [32]. The optimal range for the mean inter item correlation are between 0.2 and 0.4 [32]. However values in the range 0.1-0.5 are still acceptable [33].

\section{TABLE 4: RELIABILITY COMPARISON OF THE PRESENT} STUDY.

\begin{tabular}{|l|c|c|c|}
\hline Instruments & \multicolumn{2}{|c|}{$\begin{array}{c}\text { Cronbach's Alpha } \\
\text { value }\end{array}$} & $\begin{array}{c}\text { Inter-item } \\
\text { correlatio } \\
\mathrm{n}\end{array}$ \\
\hline $\begin{array}{l}\text { USMEQ-i } \\
\text { (domain (number } \\
\text { of item)) }\end{array}$ & $\begin{array}{c}\text { Yusoff } \\
(2012)\end{array}$ & $\begin{array}{c}\text { Present } \\
\text { study }\end{array}$ & $\begin{array}{c}\text { Present } \\
\text { study }\end{array}$ \\
\hline $\begin{array}{l}\text { Emotional } \\
\text { Control (9) }\end{array}$ & $0.86-0.91$ & 0.64 & 0.2 \\
\hline $\begin{array}{l}\text { Emotional } \\
\text { Maturity (8) }\end{array}$ & $0.82-0.91$ & 0.58 & 0.2 \\
\hline Emotional & $0.80-0.86$ & 0.36 & 0.1 \\
\hline
\end{tabular}

\begin{tabular}{|c|c|c|c|}
\hline $\begin{array}{l}\text { Conscientiousnes } \\
\text { s (5) }\end{array}$ & & & \\
\hline $\begin{array}{l}\text { Emotional } \\
\text { Awareness (5) }\end{array}$ & $0.74-0.83$ & 0.51 & 0.2 \\
\hline $\begin{array}{l}\text { Emotional } \\
\text { Commitment (4) }\end{array}$ & $0.59-0.77$ & 0.16 & 0.2 \\
\hline $\begin{array}{l}\text { Emotional } \\
\text { Fortitude (4) }\end{array}$ & $0.63-0.72$ & 0.48 & 0.1 \\
\hline $\begin{array}{l}\text { Emotional } \\
\text { Expression (4) }\end{array}$ & $0.60-0.75$ & 0.48 & 0.2 \\
\hline Faking Index (7) & $0.76-0.89$ & 0.42 & 0.1 \\
\hline $\begin{array}{l}\text { Computer } \\
\text { Attitude Scale }\end{array}$ & $\begin{array}{l}\text { Ibrahim } \\
\text { et.al. } \\
\text { (2011) }\end{array}$ & $\begin{array}{l}\text { Present } \\
\text { study }\end{array}$ & $\begin{array}{l}\text { Present } \\
\text { study }\end{array}$ \\
\hline Affective (8) & 0.60 & 0.73 & 0.3 \\
\hline Cognitive (13) & 0.70 & 0.88 & 0.4 \\
\hline Behaviour (8) & 0.80 & 0.76 & 0.3 \\
\hline
\end{tabular}

\section{Emotional Intelligence}

Based on the findings, it is reported that the overall level of emotional intelligence is Average (Mean $=2.75$, $\mathrm{SD}=0.32$ ). 26 of the respondents were classified as Average emotional intelligence and 16 with high emotional intelligence. The category was determine from the USMEQ-i manual [10], where the mean domain score is categories as follow; $0-1.20=$ Low, $1.21-2.80=$ Average and $2.81-4.00=$ High. Among all the domains, only Emotional Fortitude and Emotional Expression ware categories as High, due to mean score of 3.59 and 3.11 respectively (Table 5).

TABLE 5: EMOTIONAL INTELLIGENCE DOMAIN MEAN VALUE, STANDARD DEVIATION AND CATEGORY.

\begin{tabular}{|l|c|c|c|}
\hline EI Domains & Mean & $\begin{array}{c}\text { Std } \\
\text { Deviation }\end{array}$ & Category \\
\hline $\begin{array}{l}\text { Emotional } \\
\text { Intelligence }\end{array}$ & 2.75 & 0.32 & Average \\
\hline Emotional Control & 2.60 & 0.41 & Average \\
\hline Emotional Maturity & 2.78 & 0.44 & Average \\
\hline $\begin{array}{l}\text { Emotional } \\
\text { Conscientiousness }\end{array}$ & 2.80 & 0.39 & Average \\
\hline $\begin{array}{l}\text { Emotional } \\
\text { Awareness }\end{array}$ & 2.58 & 0.50 & Average \\
\hline $\begin{array}{l}\text { Emotional } \\
\text { Commitment }\end{array}$ & 2.54 & 0.49 & Average \\
\hline $\begin{array}{l}\text { Emotional } \\
\text { Fortitude }\end{array}$ & 3.59 & 0.48 & High \\
\hline $\begin{array}{l}\text { Emotional } \\
\text { Expression }\end{array}$ & 3.11 & 0.54 & High \\
\hline
\end{tabular}

Based on the findings described in Table 6 it is reported that there is no significant difference between the overall levels of emotional intelligence between the groups of; male and female, computer ownership and level of CGPA. Table 7 presents the levels of emotional intelligence for the same demographic profile but for each of the emotional intelligence 
domain. Based on the findings, there was no significant difference between all the groups for those domains.

\section{Computer Attitude}

Based on the findings it was reported that the overall attitude is positive (mean $=113.5, \mathrm{SD}=15.6)$, the other domains affective (mean= 31.4, $\mathrm{SD}=5.1$ ), cognitive (mean=52.4, SD=7.6) and behaviour (mean=29.7, $\mathrm{SD}=5.4$ ) were also all rated as positive (Table 8). It was also found that all computer attitude domains (affective, behaviour and cognitive) were also positive (Table 9)

TABLE 6: DEMOGRAPHIC PROFILES AND EMOTIONAL INTELLIGENCE

\begin{tabular}{|c|c|c|c|c|}
\hline Profile & Category & $\begin{array}{c}\text { Emotional } \\
\text { intelligence (EI) }\end{array}$ & Mean, SD & Significance \\
\hline \multirow{2}{*}{ Gender } & Male & $\begin{array}{c}\text { Low }=0 \\
\text { Average }=19 \\
\text { High }=5\end{array}$ & $\begin{array}{c}\text { Mean }=2.68 \\
\text { (Average) } \\
\mathrm{SD}=0.28\end{array}$ & \multirow{2}{*}{$\begin{array}{l}\text { There was no significant difference } \\
\text { between male and female } \\
\text { respondents towards the overall level } \\
\text { of EI }(p>0.05) \text {. }\end{array}$} \\
\hline & Female & $\begin{array}{c}\text { Low }=0 \\
\text { Average }=7 \\
\text { High }=11\end{array}$ & $\begin{array}{l}\text { Mean }=2.84 \\
\quad(\text { High }) \\
\mathrm{SD}=0.34\end{array}$ & \\
\hline \multirow{2}{*}{$\begin{array}{l}\text { Computer } \\
\text { Ownership }\end{array}$} & Yes & $\begin{array}{c}\text { Low }=0 \\
\text { Average }=23 \\
\text { High }=16\end{array}$ & $\begin{array}{c}\text { Mean }=2.77 \\
\text { (Average) } \\
\mathrm{SD}=0.32\end{array}$ & \multirow{2}{*}{$\begin{array}{l}\text { There was no significant difference } \\
\text { between computer ownership } \\
\text { between respondents towards the } \\
\text { overall level of EI. }\end{array}$} \\
\hline & No & $\begin{array}{c}\text { Low }=0 \\
\text { Average }=3 \\
\text { High }=0\end{array}$ & $\begin{array}{l}\text { Mean }=2.52 \\
\text { (Average) } \\
\mathrm{SD}=0.90\end{array}$ & \\
\hline \multirow{2}{*}{ CGPA } & High & $\begin{array}{c}\text { Low }=0 \\
\text { Average }=13 \\
\text { High }=13\end{array}$ & $\begin{array}{c}\text { Mean }=2.79 \\
\text { (Average) } \\
\mathrm{SD}=0.36\end{array}$ & \multirow{2}{*}{$\begin{array}{l}\text { There was no significant difference } \\
\text { between levels of CGPA of the } \\
\text { respondents towards the overall level } \\
\text { of EI and domains of EI ( } p>0.05) \text {. }\end{array}$} \\
\hline & Low & $\begin{array}{c}\text { Low }=0 \\
\text { Average }=13 \\
\text { High }=3\end{array}$ & $\begin{array}{l}\text { Mean }=2.69 \\
\text { (Average) } \\
\mathrm{SD}=0.23\end{array}$ & \\
\hline
\end{tabular}

TABLE 7: DEMOGRAPHIC PROFILES AND DOMAINS OF EMOTIONAL INTELLIGENCE.

\begin{tabular}{|c|c|c|c|c|c|c|}
\hline \multirow{3}{*}{ USMEQ-i domain } & \multicolumn{6}{|c|}{ Emotional intelligence category } \\
\hline & \multicolumn{2}{|c|}{ Gender } & \multicolumn{2}{|c|}{ Computer ownership } & \multicolumn{2}{|c|}{ CGPA } \\
\hline & Male & Female & Yes & No & Low & High \\
\hline Emotional Control & Average & Average & Average & Average & Average & Average \\
\hline Emotional Maturity & High & Average & Average & Average & Average & Average \\
\hline $\begin{array}{l}\text { Emotional } \\
\text { Conscientiousness }\end{array}$ & Average & High & High & Average & Average & High \\
\hline $\begin{array}{l}\text { Emotional } \\
\text { Awareness }\end{array}$ & Average & Average & Average & Average & Average & Average \\
\hline $\begin{array}{l}\text { Emotional } \\
\text { Commitment }\end{array}$ & Average & Average & Average & Average & Average & Average \\
\hline $\begin{array}{l}\text { Emotional } \\
\text { Fortitude }\end{array}$ & High & High & High & High & High & High \\
\hline $\begin{array}{l}\text { Emotional } \\
\text { Expression }\end{array}$ & High & High & High & High & High & High \\
\hline
\end{tabular}


TABLE 8: DEMOGRAPHIC PROFILE AND COMPUTER ATTITUDE

\begin{tabular}{|c|c|c|c|}
\hline Profile & Category & Mean, SD & Significance \\
\hline \multirow[b]{2}{*}{ Gender } & Male & $\begin{array}{l}\text { Mean }=112.8 \text { (Positive) } \\
\text { SD }=16.5\end{array}$ & \multirow{2}{*}{$\begin{array}{l}\text { There was no significant difference } \\
\text { between male and female respondents } \\
\text { towards the overall attitude towards } \\
\text { computers and between the domains } \\
(\mathrm{p}>0.05) \text {. }\end{array}$} \\
\hline & Female & $\begin{array}{l}\text { Mean }=114.4 \text { (Positive) } \\
\mathrm{SD}=14.8\end{array}$ & \\
\hline \multirow{2}{*}{$\begin{array}{l}\text { Computer } \\
\text { Ownership }\end{array}$} & Yes & $\begin{array}{l}\text { Mean }=113.3 \text { (Positive) } \\
\mathrm{SD}=15.4\end{array}$ & \multirow{2}{*}{$\begin{array}{l}\text { There was no significant difference } \\
\text { between male and female respondents } \\
\text { towards the overall attitude towards } \\
\text { computers and between the domains } \\
(\mathrm{p}>0.05) \text {. }\end{array}$} \\
\hline & No & $\begin{array}{l}\text { Mean }=116.0(\text { Positive }) \\
S D=21.9\end{array}$ & \\
\hline \multirow[b]{2}{*}{ CGPA } & High & $\begin{array}{l}\text { Mean }=114.6 \text { (Positive) } \\
\text { SD }=17.4\end{array}$ & \multirow{2}{*}{$\begin{array}{l}\text { There was no significant difference } \\
\text { between male and female respondents } \\
\text { towards the overall attitude towards } \\
\text { computers and between the domains } \\
(\mathrm{p}>0.05) \text {. }\end{array}$} \\
\hline & Low & $\begin{array}{l}\text { Mean }=111.6 \text { (Positive) } \\
\mathrm{SD}=13.0\end{array}$ & \\
\hline
\end{tabular}

TABLE 9: DEMOGRAPHIC PROFILE AND ATTITUDE TOWARDS COMPUTERS DOMAINS

\begin{tabular}{|l|c|c|c|c|c|c|}
\hline \multirow{2}{*}{$\begin{array}{l}\text { Computer Attitude } \\
\text { domains }\end{array}$} & \multicolumn{2}{|c|}{ Category } & \multicolumn{2}{c|}{ Computer ownership } & \multicolumn{2}{c|}{ CGPA } \\
\cline { 2 - 6 } & Male & Female & Yes & No & Low & High \\
\cline { 2 - 7 } & Positive & Positive & Positive & Positive & Positive & Positive \\
\hline Affective & Positive & Positive & Positive & Positive & Positive & Positive \\
\hline Cognitive & Positive & Positive & Positive & Positive & Positive & Positive \\
\hline Behaviour
\end{tabular}

\section{E. Relationship between computer attitude and emotional intelligence.}

Based on the Spearman correlation analysis performed between emotional intelligence, computer attitudes and both its domains, most of the correlation strength was weak and insignificant. The relationship between emotional intelligence and attitude towards computer was positive, weak (rho=0.103, $\mathrm{p}=0.512$ ) and non significant. The male students were reported to have an overall positive non significant relationship (rho=0.292, $\mathrm{p}=0.166$ ) between emotional intelligence and attitude towards computers. Where else female students had a negative non significant relationship (rho=-.147, $\mathrm{p}=0.561$ ) between emotional intelligence and attitude towards computer. Students that owned computers were found to have very weak non significant positive relationship ( $\mathrm{rho}=0.080, \mathrm{p}=0.627$ ) and student who did not have a strong positive relationship (rho=1.000, $\mathrm{p}=0.000$ ). CGPA level in both the cases of computer attitude (high (rho=-.039, $\mathrm{p}=0.849)$ and low (rho=-.395, $\mathrm{p}=0.130)$ were found to have a very weak, negative and non significant relationship between emotional intelligence and attitude towards computers.

\section{DISCUSSION}

Based on the findings, it was reported that the overall level of emotional intelligence and some of the domains of emotional intelligence is average for these students. Referring to USMEQ-i manual the following description (Table 10) was identified for each of the domains of emotional intelligence domains [10]. Two domains of emotional intelligence were categorised as high, emotional fortitude and emotional expression as diplomatic and communicative skills are high when there is a cultural difference in an education setting [34]. This might explain the reason for high emotional fortitude as Malaysia is a multi-racial country and individual are educated to be aware and tolerant with every race. 
TABLE 1ODESCRIPTION ON THE LEVELS OF EMOTIONAL INTELLIGENCE DOMAINS

\begin{tabular}{|l|c|l|}
\hline EI Domains & Category & \multicolumn{1}{c|}{ Description } \\
\hline $\begin{array}{l}\text { Emotional } \\
\text { Intelligence }\end{array}$ & Average & $\begin{array}{l}\text { Indicates that the person is reasonably skilful at perceiving, expressing, } \\
\text { understanding, motivating, controlling and regulating your emotions. }\end{array}$ \\
\hline $\begin{array}{l}\text { Emotional } \\
\text { Emotrol } \\
\text { Maturity }\end{array}$ & Average & $\begin{array}{l}\text { Indicates that the person is able to control their disruptive emotions and } \\
\text { impulsive feeling in certain situations. However, they tend to lose control } \\
\text { once they are under pressure. }\end{array}$ \\
\hline $\begin{array}{l}\text { Emotional } \\
\text { Conscientiousness }\end{array}$ & Average & $\begin{array}{l}\text { Indicates that the person is reasonably skilful at facilitating their emotion } \\
\text { toward intended goals. However they are sometimes unmotivated with } \\
\text { their work. }\end{array}$ \\
\hline $\begin{array}{l}\text { Emotional } \\
\text { Awareness }\end{array}$ & Average \\
\hline $\begin{array}{l}\text { Emotional } \\
\text { Commitment } \\
\text { certain situation. }\end{array}$ & $\begin{array}{l}\text { Indicates that they are reasonably skilful in understanding theirs and } \\
\text { other's feelings. }\end{array}$ \\
\hline $\begin{array}{l}\text { Emotional } \\
\text { Fortitude }\end{array}$ & Average & $\begin{array}{l}\text { Indicates that they are willing to align their emotions with others toward } \\
\text { achieving common goals but not at the expense of sacrificing their own } \\
\text { feelings }\end{array}$ \\
\hline $\begin{array}{l}\text { Emotional } \\
\text { Expression }\end{array}$ & High & $\begin{array}{l}\text { Indicates that they are skilful in negotiating and resolving disagreements } \\
\text { without hurting other people's feelings. People consider them as highly } \\
\text { diplomatic individuals. }\end{array}$ \\
\hline
\end{tabular}

The female students were categories as High EI (mean $=2.84$ ) when compared to the male students (mean $=2.68$ ) whom were categories as Average EI. Respondents that owned a computer (mean $=2.77$ ) and had high CGPA (mean=2.79) had higher mean value when compared to their significant other, but all these groups were found to be categories as average. The differences between these groups were found to be not significant statistically.

In comparing the domains of emotional intelligence, it was found that emotional fortitude and expression were high, where else other domains were average. There were some exceptional cases that can be reported when these domains were compared based on the demographic profile of the respondents, such as:-

i. Emotional maturity for male students was higher than female students.

ii. Emotional conscientiousness of female students was higher than male students.

iii. Students who owned computers proved to show higher emotional conscientiousness.

iv. Higher CGPA also proves to show higher emotional conscientiousness

The overall attitude towards computers and its domain were found to be positive. The affective, cognitive and behavioural domain was also found to be positive in all cases of different genders, computer ownership and level of CGPA. According to Ibrahim et.al. (2011), a positive outcome in the domain of cognitive proves that students have a positive believe that computers are important in improving their work quality and has a significant impact for their everyday use and also towards their future. Based on the items from the questionnaire it can be deduced that a positive outcome in the affective domain portrays that students enjoy using computer and aware of its benefits towards their education. Where else a positive outcome in the behavioural domain portrays student's intention to use computers is not seen as chore and their willingness to use it based on their own initiative. Female students, high CGPA students and students whom did not own computers had more positive attitude when compared to their significant other.

The overall relationship between emotional intelligence and attitude towards computer was positive but however weak and not significant. Female student's emotional intelligence was negatively correlated with attitude towards computers, where else male students correlation was more positive and stronger. Ownership of computer had an overall positive correlation in this relationship; however it was found that student whom did not own computer had a stronger positive relationship in comparison to students that did own computers. Students with high level of CGPA were also found to have negative relationship when emotional intelligence and attitude towards computer is concern. High CGPA students were mostly female students $($ Female $=15$, Male $=11$ ). Thus the same pattern was also detected for this relationship when female student were compared to the male students relationship between emotional intelligence and attitude towards computer. The low CGPA group, with 13 male students and three female students had a similar relationship with as per how male students are compared. As all the relationship was found to be not significant statistically when groups were compared, the possible reasoning was small sample size. 


\section{SUMMARY}

The overall levels of emotional intelligence for polytechnic students were average. However their level of emotional fortitude and emotional expression were high. The possible explanation for this is due to the diverse culture and race that Malaysians live by has moulded them to be an emotionally sensitive toward people from different backgrounds. Students were also found to have a positive attitude towards computers in all domains (affective, behavioural and cognitive). Computers have been accepted as an important tool in their education and they are well aware of its benefits to them in different context such as entertainment, communication and etc. The relationship between emotional intelligence and attitude towards computer is positive but very weak. Female students were found to have a negative relationship and male students a positive relationship in this context. Other factors such as CGPA and computer ownership did not affect this relationship. So does emotion intelligence effects how students perceive computers? Further research into the domains of emotional intelligence and how it is relates to student's attitude towards computers should be looked in further for these answer.

\section{REFERENCE}

[1] Arifin, T.F.T., Nordin, H. \& Karim, A.M.A (2008). What Predicts Attitudes Toward Computer?, The Malaysian Education Deans' Council (MEDC) Journal. [Online]. Available http://web.usm.my/education/medc/vol2/9.\%20wh at $\% 20$ predicts $\% 20$ attitudes $\% 20$ toward $\% 20$ comput er.pdf

[2] Kaiser, R., \& Oertel, K. Emotions in HCI: An Affective E-Learning System. Proceedings Of The HCSNET Workshop On Use Of Vision In HumanComputer Interaction, Vol. 56, 2006, pp. 105-106, Australian Computer Society, Inc.

[3] Cristescu, I. "Emotions in Human-Computer Interaction: The Role of Nonverbal Behaviour In Interactive Systems". Informatica Economică, 2(2), 2008, pp 110-116.

[4] Whang, M., \& Lim, J. A Physiological Approach to Affective Computing (2008). Affective Computing: Focus on Emotion Expression, Synthesis, and Recognition, Vienna: ITech Education and Publishing, pp. 310-318 [Online]. Available

http://www.intechopen.com/source/pdfs/5190/InTe ch-

A_physiological_approach_to_affective_computin g.pdf

[5] Zeidner, M., Matthews, G., \& Roberts, R. D. What We Know about Emotional Intelligence: How it affects learning, work, relationship and our mental health. Health (San Francisco). Cambridge, Massachusetts: The MIT Press, 2009, p 228

[6] Lee, I. S.(2008). Emotion, Emotional Intelligence, and e-Learning. Dasansejongackr. [Online]. Available:

from http://dasan.sejong.ac.kr/ inlee/set/set/articles/ICo ME2011_K_14.pdf

[7] Goldsworthy, R.. Supporting the Development of Emotional Intelligence through Technology. Computers in the Schools. 19(1), 2002, pp 119-148. doi:10.1300/J025v19n01_10

[8] Al-Faouri, A. H. A. "Investigating The Impact of Emotional Intelligence On Technology Learning". International Journal of Engineering \& Technology, 11(3), 2011, pp 58-78.

[9] Salovey, P., \& Mayer, J. D.Emotional Intelligence. Imagination, Cognition, and Personality, 9, 185 211. Bantam, 1990, p 189.

[10] Yusoff, M. S. B., Rahim, A. F. A., \& Esa, A. R. The USM Emotional Quotient Inventory (USMEQi) Manual. Kota Bharu: KKMED Publications, Malaysia, 2010.

[11] Goleman, D. Emotional Intelligence: Why It Can Matter More Than IQ. Bloomsbury Publishing PLC, 1996.

[12] Serrat, B. O. Understanding and Developing Emotional Intelligence. Knowledge Solutions:Asian Development Bank, (June), 49, 2009.

[13] Behnke, C., \& Greenan, J. P. "The Relationship between Emotional Intelligence and Attitudes toward Computer-based Instruction of Postsecondary Hospitality Students". Journal of Career and Technical Education, 26(1), 2011, pp 62-84.

[14] Berenson, R., Boyles, G., \& Weaver, A. (2008). Emotional Intelligence as a Predictor for Success in Online Learning. The International Review of Research in Open and Distance learning, 9(2) [Online]. Available http://www.irrodl.org/index.php/irrodl/article/view /385/1036

[15] Mayer, J. D., Roberts, R. D., \& Barsade, S. G. (2008) . "Emerging Research In Emotional Intelligence". Annual Review of Psychology, 59, , pp 507-536 [Online]. Available: http://www.unh.edu/emotional_intelligence/EI Assets/Reprints...EI Proper/EI2008 MayerRichardsBarsade 2008 Draft Preprint.pdf

[16] Hogg, M., \& Vaughan, G. Social Psychology (4th edition). London: Prentice-Hall, 2005, p 150.

[17] Kutluca,T. "A Study on Computer Usage And Attitudes Toward Computers of Prospective Preschool Teacher". International Journal On New 
Trends In Education And Their Implications, 2(1). 2011

[18] Ibrahim, N., Wong, S.L., \& Ayub, A.F.M. "Sikap terhadap Komputer di kalangan Pelajar ICT Tingkatan Empat”. Jurnal Teknologi Pendidikan Malaysia.1(1), 2011

[19] McLeod, S. A. (2009) Simply Psychology; Attitude [Online]. Available: http://www.simplypsychology.org/attitudes.html

[20] Smith, B., Caputi, P. and Rawstorne P. "Differentiating Computer Experience and Attitudes toward Computers: An Emprical Investigation". Computers in Human Behavior, 16, 2000, 59-81.

[21] Abidin, M.J.Z., Pour-Mohammadi, M., Shoar, N.S., See, T.H.C., \& Jafre, A.M. “ A Comparative Study of Using Multimedia Annotation and Printed Textual Glossary in Learning Vocabulary". International Journal of Learning and Development, 1(1), 2011, pp 82-90. doi:10.5296/ijld.v1i1.1070

[22] Wong,S.L., Ibrahim,N,. \& Ayub, A.F.M. "Learning Strategies as Correlates of Computer Attitudes: A Case Study among Malaysian Secondary School Students". International Journal of Social Science and Humanity, 2( 2).2012.

[23] Yushau, B. "Computer Attitude, Use, Experience, Software Familiarity and Perceived Pedagogical Usefulness: The Case Of Mathematics Professors". Eurasia Journal of Mathematics, Science and Technology Education, 2(3). 2006

[24] Sam, H. K., Othman, A. E. A., \& Nordin, Z. S. "Computer Self-Efficacy, Computer Anxiety, and Attitudes toward the Internet: A Study among Undergraduates in UNIMAS". Educational Technology \& Society, 8 (4), 2005, pp 205-219.

[25] Hong, K.S., Ridzuan, A. A., \& Kuek, M.K.. "Students' attitudes toward the use of the Internet for learning: A study at a university in Malaysia". Educational Technology \& Society, 6(2), 2003, pp 45-49, (ISSN 1436-4522)

[26] Adebowale, O.F, Adediwura, A.A., Bada, T. A. "Correlates of Computer Attitude among Secondary School Students in Lagos State, Nigeria”. International Journal of Computing and ICT Research, 3(2), 2009, pp 20 - 30.

[27] Saadé, R. G., \& Kira, D. "The Emotional In ELearning". Journal of Asynchronous Learning Networks, 13(4), 2009, pp 57-73.

[28] Jackson, L. A., Ervin, K. S., Gardner, P. D. \& Schmitt, N. "Gender and the Internet: Women communicating and men searching". Sex Roles, 44(5), 2001, pp 363-379.
[29] Teo, T. "Pre-service teachers' attitudes towards computer use: A Singapore survey". Australasian Journal of Educational Technology, 24(4), 2008, 413-424.

[30] Yusoff, M.S.B.Stability Of USMEQ-I in Measuring Emotional Intelligence In Medical Students. ASEAN Journal of Psychiatry, 13 (1). 2012.

[31] Pallant, J. SPSS survival manual: A step-by-step guide to data analysis using SPSS for Windows (Version 15) (3rd ed.). New York: Open University Press. 2007

[32] Cox, T., \& Ferguson, E. Measurement of The Subjective Work Environment. Work And Stress, 8, 1994, pp 98-109.

[33] Boler, M. Feeling Power: Emotions and Education. London: Routledge. 1999.

Jeya Amantha Kumar is currently a PhD student in the Centre of Instructional Technology and Multimedia, University Sains Malaysia, Pulau Pinang, Malaysia. Her research interest is in the field of emotional intelligence, emotions in computing and aesthetic user interface. She has been working in the Malaysian polytechnic educational system as a lecturer for the past 9 years. She is currently attached to the Electrical Engineering Department of Polytechnic Tuanku Sultanah Bahiyah, Kulim, Kedah.

Assoc. Prof. Dr. Balakrishnan Muniandy is a lecturer in the Centre of Instructional Technology and Multimedia, University Sains Malaysia, Pulau Pinang, Malaysia. In teaching, he has been focusing on multimedia authoring, management and evaluation of multimedia project, instructional design and delivery and research methods and issues in instructional multimedia. Dr. Balakrishnan received his $\mathrm{PhD}$ in Educational Leadership (Educational Technology) from the Department of Leadership, Technology \& Administration (DELTA), University of Oregon, United States of America.

Assoc. Prof. Dr. Wan Ahmad Jaafar Wan Yahaya is a lecturer in the Centre of Instructional Technology and Multimedia, University Sains Malaysia, Pulau Pinang, Malaysia. In teaching, he has been focusing on Graphic 2D, 3D \& Animation, Multimedia Project Management, Multimedia in Education, and 3D Visualisations and Animations. Dr. Wan Ahmad Jaafar received his PhD in Multimedia in Education from the University of Leeds, United Kingdom. 